\title{
THE STRUCTURE OF THE BUILDING LIFE CYCLE ASSESSMENT (LCA) FOR SELECTING SUSTAINABLE MATERIALS IN RESIDENTIAL COMPLEXES IN TEHRAN
}

\author{
Javad Divandari \\ ${ }^{1}$ Department of architecture,university of kashan,kashan,Iran \\ Farbod Najari \\ Department of architecture,Sari Branch,Islamic Azad University, Sari, IRAN
}

\begin{abstract}
The world is now faced with an imbalance in the biological systems. The emergence of the phenomenon as climate change in the world can seriously take at risk the biological future of the world and causes the extinction of life and organisms on Earth. Given that the main reason for this phenomenon is the greenhouse gas emissions, buildings cause about half of these emissions, as a sustainable building design will cause to reduce negative effects caused by the improper use of materials and produce wastes. Therefore, sustainability approach based on the needs of today's generation using renewables resources and in opposition to non-renewable resources can be expressed. In fact, sustainable building materials should have the lowest risk to human health. So materials should be investigated from design to implementation and operation to understand the sustainability concepts of building. The present article will review the assessment of sustainable materials to use in residential buildings in the area of Tehran, and the vision of research is to provide solutions for assessing the sustainable architecture through understanding the new way of building life cycle analysis (LCA) of materials in building as a tool to measure. So the research questions are: How much selecting sustainable materials based on LCA in the design of residential complexes in Tehran is effective in reducing energy consumption of these buildings? And it investigates how quantitative and qualitative sustainable materials based on assessment system of environmental cycle in residential complex in Tehran.
\end{abstract}

Keywords: Sustainable materials, Life Cycle of building, Embodied Energy, LCA

\section{INTRODUCTION}

Building materials determine a considerable part of the energy consumed by buildings. Building materials include amounted to 60 percent of the construction costs of the building (Arayela,2005). In another study, it is referred to the percentage between $50-60 \%$ of the total construction costs, but what is clear is that this percent in developing countries (where most cases use imported technologies in the field of housing) constitute over 65 percent of total construction costs (Ogunsemi, 2010). On the other hand, various pollutions of urban spaces are also one of the negative reflections of the non-normative development of housing in cities. So considering the required development of housing and a wide range of issues created, explaining sustainable architecture by reducing pollutions caused by housing development is essential. Thus, considering that the daily production of dust and debris in Tehran is five times of municipal wastes and daily 40 tons of building waste is generated in the city (Mohammadi, 2007). In this paper, using the building life cycle analysis (LCA) as one of the new methods for assessing the environmental capacity of building methods and products (equipment and facilities) during their life cycle from raw material stage to the time of their disposal should take step in the discussion of sustainable architecture in order to respond to today's problems in the field of architecture and also in the environmental sector in Tehran. This article is composed of five parts. Thus, after the theoretical foundations that are about sustainable architecture and introducing building life-cycle analysis, the research methodology is introduced. The study area has been studied and the results and the conclusions are presented and discussed. 


\section{THEORETICAL FOUNDATIONS}

In the theoretical foundation of this research in the first stage, the concepts of LCA in line with sustainable architecture is described and it focus on the method investigated and tools used in the built environment. In the second stage, sustainability assessment in buildings based on the assessment system of environmental cycle and the use of this method from the primary stages, study and design to before operation of the residential complex in the region of Tehran is discussed. Finally, the results of this work can be used by stakeholders as an important reference in the LCA, which includes update procedures in perspective and analysis methods to protect the environment and thus achieve sustainable development in the region of Tehran.

\section{SUSTAINABLE ARCHITECTURE}

Sustainability is any development that according to the requirements of environmental, economic and social to meet the structural needs of current and future societies is created. A building is sustainable that regard to its natural context is flexible, durable, and with high quality and to be formed with regard to the identity of its community and abled to create comfort and relaxation of man due to accrued performance. Stable and homogeneous design is a design that something as a part of a larger whole is well considered (Rocky Mountain, 1998). On the other hand, according to the diversity of the architectural word, it's hard to point a specific case that architecture had a minor impact on the natural environment. Environmental factors that architecture influences them, including (technology, materials, energy, water, transport) wastes resulting from construction of buildings, the resources that are consumed during the life of the building by residents, and finally the sources and various wastes that somehow connected with the surrounding environment to be included. According to available figures, energy consumption of buildings alone consumes around half of total energy consumption of the world.

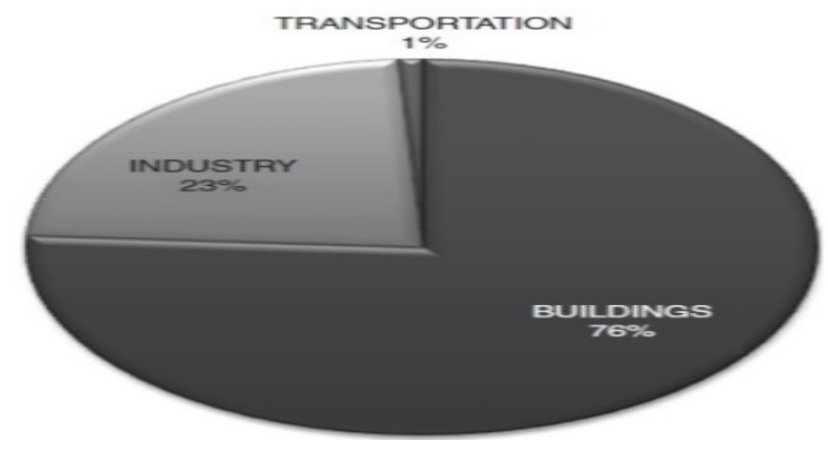

Figure 1-world energy consumption in 2008 based on the different parts American Institute of Architects (AIA) and Architecture 2030, 2009)

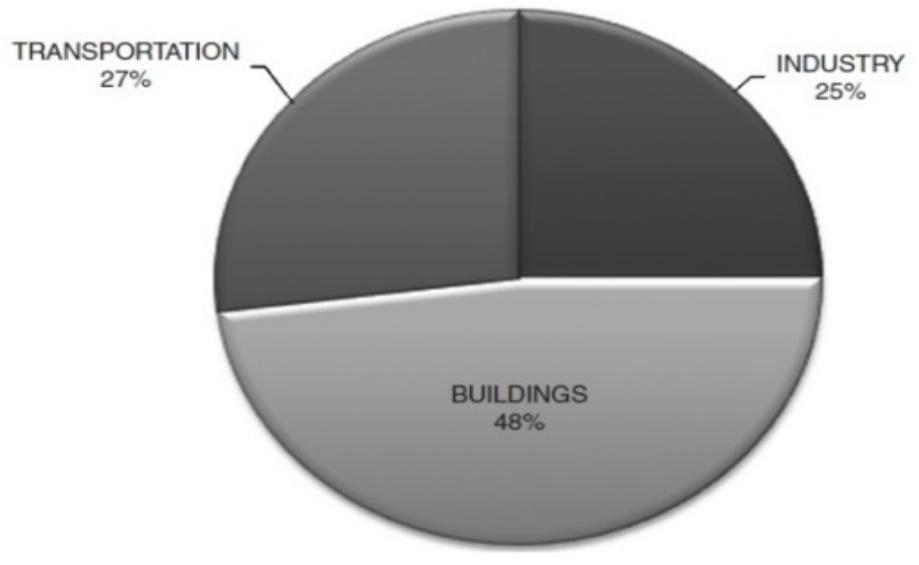

Figure 2. The consumption of electricity in the world in 2008 
At the same time and simultaneously, buildings over the years consume a huge amount of natural resources and exchanged to the wastes and buildings wastes. Buildings consumed about 50 percent of

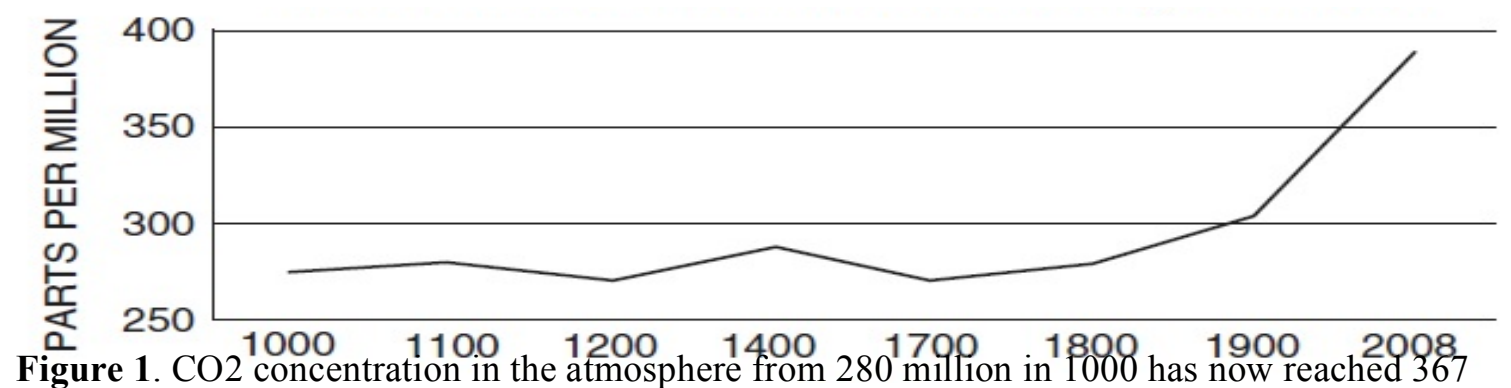

million.

(Current and long term historical data compiled by Scripps, Earth Policy Institute,

ESRL/NOAA, World watch)

the world's raw materials that more than 70 percent of the consumption cases are nonrenewable, and buildings are responsible for producing more than $36 \%$ of wastes in the total world (Graham, 2002). Buildings produce about a third of total world greenhouse gases (GHG) that this figure is increasing in recent years.

This amount will be increased about 8.6 billion tonnes in 2004 and due to the increasing process in 2030 in amount of doubled amount and reached about 15.6 billion tons (IPCC, 2007). A variety of factors are involved in this sector, which we refer to three of them that have a significant impact on the libertine increase:

1. Excessive increase in population and the availability of available resources;

2. Building processes and uncertain longevity of the building;

3. Technology and Materials

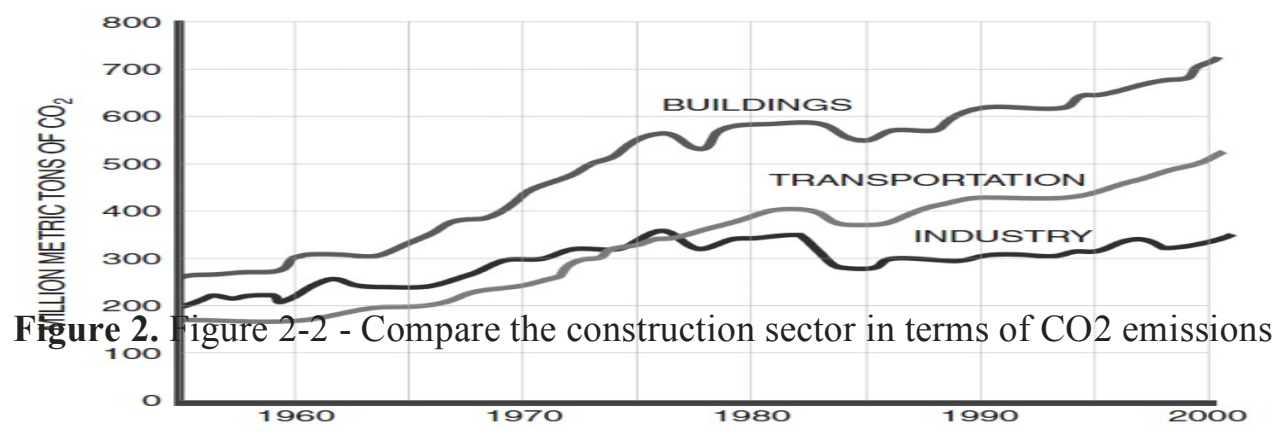

(U.S. Energy Information Administration statistics (USDE 2008), Architecture2030)

\section{BUILDING LIFE CYCLE ANALYSIS}

One of the methods of assessing the sustainability of buildings and especially the sustainability of building materials is analysis of the life cycle of the building. LCA of 1990 was entered the 
construction sector, and is an important tool to assess it (Fava, 2006; Taborianski, 2004). Life cycle analysis of building is a method for assessing the capacity of environmental of construction methods and products (equipment and facilities) during their life cycle from raw stage until their disposal (Sonnemann et al, 2003; Hobday, 2006; Warburg, 2005). Klopffer believes LCA is a very wide method, because it gathers information about the structure, analysis of environmental impacts of the building and the quality of data arising from the effects in a comprehensive review (Klopffer, 2006). In the following, how to reduce energy consumption using this approach is explained.

\section{REDUCE ENERGY CONSUMPTION OF BUILDINGS WITH LCA APPROACH}

Reducing energy consumption in buildings must be accompanied by reducing the number of sources of energy, as well as created a fundamental change in primary and secondary energy consumption (Sartori and Hestnes, 2007).

\section{REDUCE TOTAL ENERGY CONSUMPTION}

When we consider all phases related to the construction of a house, and add items such as drinking water, cooking, lighting and the use of equipment to it. The ratio of the energy consumption among the house that is built with sustainability standards and a house that is built in common form from 10: 1 to $1: 7.3$ is reduced. This figure is 1:5.2 when we consider all environmental items and in terms of warming potential of earth decreases to 1:4.2. Elsewhere it is observed that when we reach to carbon footprint, this reduction shows a ration equivalent to 1: 2.2, respectively. Despite all existing aspects, architects and designers should not pay attention only to aspects related to energy consumption but also should pay attention to the materials used and remaining of the building that remains at the end of its useful life. In another study, they concluded that transport of materials to the site leaves the least environmental impact than other factors (Blengini and Dicarlo, 2010).

Table 1: Effects of transporting materials from industrial production unit to the project site

\begin{tabular}{llll}
\hline Impact category & $\begin{array}{l}\text { Lorry, } \\
\text { road } \\
\mathrm{m}_{1}\end{array}$ & $\begin{array}{l}\text { Freight } \\
\text { rail } \\
\mathrm{m}_{2}\end{array}$ & $\begin{array}{l}\text { Transoceanic } \\
\text { freight ship } \\
\mathrm{m}_{3}\end{array}$ \\
\hline Primary energy demand $(\mathrm{MJ}-\mathrm{Eq} / \mathrm{km})$ & 3.266 & 0.751 & 0.170 \\
Global Warming Potential $(\mathrm{kg} \mathrm{CO}-\mathrm{Eq} / \mathrm{km})$ & 0.193 & 0.039 & 0.011 \\
Water demand $(\mathrm{l} / \mathrm{km})$ & 1.466 & 1.115 & 0.097 \\
\hline
\end{tabular}

(Source: Blengini and Dicarlo, 2010)

In one study, they concluded that the primary energy for the construction of equipment of building in typical buildings and buildings with low energy consumption is approximately $45 \%$ and $60 \%$ of total energy consumption to build it. This relative increase is only due to the use of wood for making windows frame to reduce the environmental impacts. They concluded that the greatest influence in this area is related to increase the outer layers of the building, the use of windows to waste less energy, loss of energy for the construction, to stored energy of 10: 1, this means that 10 times more than what they spent energy for construction, they can provide to save in building energy (Gustavsson and Joelsson, 2010). Ferbik and Hans in 2010 with research on four houses in Belgium concluded that energy consumption due to the construction of a building with low energy consumption within a short time (less than 2 years) will be compensated. Only in houses with the least amount of energy loss (over 30 years MJ / m 3 900), the amount of energy used to manufacture them in front of their energy loss is minimal. They in recent research concluded that the return of investment on energy loss to insulate a building provides between 10 and 30 years of energy consumption of a common house (Verbeek and Hens, 2010) Baryspan, Avsen and Oscar Peliny carried out a similar study on house in Spain. In their study, it was concluded that $90 \%$ of primary energy used is consumed during the 5 years of the life of a building (Zabalza et al, 2009). In a research in the area of residential buildings, Otama and Givala concluded that the double walls to a wall in a period of 40 years have better productivity. However, the primary embodied energy of double walls and a wall in tall buildings is, respectively, $79.5 \mathrm{GJ} / \mathrm{m} 2$ and $76.3 \mathrm{GJ} / \mathrm{m} 3$. This small difference in embodied energy of these two 
types of wall with energy-saving that is expected is very different, the amount of energy consumed declined from $480 \mathrm{Gj} / \mathrm{m} 2$ to $283 \mathrm{Gj} / \mathrm{m} 2$ (Utama and Gheewala, 2000). Recently radhi in a similar study on the effect of external heating and its conductivity from the coverage concluded that the thermal conductivity depends on the heat that is stored in the structure of a building (potential) (Radhi, 2009). This explanation means that in the design, we require maximum precision in the simulation of building to achieve considered parameters for evaluation of LCA.

\subsubsection{3. environmental impact of materials (IMPRO)}

Environmental Improvement Products (IMPRO) includes the application of policies such as, strategies used in IPP, regulations related to environmental product declaration (EPD) and ecology. EPD is an accepted strategy that is used to international standards, and provides a guideline to reduce the environmental impacts of building products (EPD, 2005). EPD includes materials such as concrete, wood, and metals such as aluminum, which is shaped based on LCA and includes information on how to prepare raw materials, energy consumption, choice of materials, emissions in the atmosphere, soil and water and generating wastes (Askham, 2006). On the other hand, ecology refers to the relationship between a product and the surrounding environment. Ecology provides techniques to reduce environmental impacts during different stages of their life cycle. Sun and Pojari concluded that ecology include determining the environmental impact of the production consumption chain of products that the issue included environmental influencing factors during the design of materials, process and related activities, when 60 to $80 \%$ of its life cycle has elapsed (Sun et a., 2004). Fuel and Energy Management of America (2003) collected data and statistics in the field of annual required energy consumption in residential buildings, commercial with embodied energy (cement, ceramics, glass, steel and so on). The organization based on that information specified buildings that consume a lot of energy and produced greenhouse gases.

\section{THE ASSESSMENT OF MATERIALS IN LCA}

In this section, the dominant materials used in residential buildings in Tehran will be presented and the environmental impact of them is evaluated in the LCA method.

\section{BRICK AND TILE}

Ceramic floors consume a lot of energy during production, because so much gas is burned and used to be treated product, and cause to increase primary energy consumption. Brickworks spend around $80 \%$ of total energy consumption to processing these products. In addition, the required water to evaporate ceramic flooring is 7.5 times more than the amount ceramic of wall and brick consumes. To exterior paving of building, rubble stone is suggested instead of carpet ceramic and what about $\mathrm{Mj}$-Eq 13.45 $(86 \%)$ in primary energy consumption is saved and reduced $\mathrm{CO} 2$ emissions by as much as $0.57 \mathrm{~kg}$ $(66 \%)$. To cover the building, Fiber- Cement is a very unsatisfactory option, however today concrete than ceramic in better. Although ceramic has energy saving equivalent $6.95 \mathrm{Kg} / \mathrm{Mj}(60 \%)$ than fiber- cement, and ceramic products show $1.93 \mathrm{MJ} / \mathrm{Kg}$ (42\%) reduction in energy consumption compared to concrete. About brick, using light clay brick ( $85 \%$ clay and $15 \%$ straw) calcium silicate brick ( $9 \%$ limestone and $10 \%$ sand) considerably reduces negative environmental impacts. Although light clay brick has relatively high primary energy ( $45 \%$ of the energy produces by the natural fuel). In addition, light clay brick is neutral in terms of $\mathrm{CO} 2$ emissions, so compared to typical brick (which is published $0.27 \mathrm{CO} 2$ ) is more cost-effective (Zabalza et al., 2010).

Table 2: LCA findings from different bricks and tiles

\begin{tabular}{|c|c|c|c|c|c}
\hline $\begin{array}{c}\text { Building } \\
\text { Products }\end{array}$ & $\begin{array}{c}\text { Density } \\
(\mathrm{kg} / \mathrm{m} 3)\end{array}$ & $\begin{array}{c}\text { Thermal } \\
\text { conductivity } \\
(\mathrm{W} / \mathrm{mK})\end{array}$ & $\begin{array}{c}\text { Primary } \\
\text { required } \\
\text { energy }(\mathrm{MJ}- \\
\mathrm{Eq} / \mathrm{kg})\end{array}$ & $\begin{array}{c}\text { warming } \\
\text { potential of } \\
\text { earth } \\
(\mathrm{Kg} \mathrm{CO} 2-\mathrm{Eq} / \\
\mathrm{kg})\end{array}$ & $\begin{array}{c}\text { Amount of water } \\
\text { needed } \\
(\mathrm{L} / \mathrm{kg})\end{array}$ \\
\hline $\begin{array}{c}\text { Ordinary } \\
\text { brick }\end{array}$ & 1800 & 0.95 & 3.562 & 0.271 & 1.890 \\
\hline Clay brick & 1020 & 0.29 & 6.265 & -0.004 & 1.415 \\
\hline
\end{tabular}




\begin{tabular}{|c|c|c|c|c|c}
\hline $\begin{array}{c}\text { Sand-lime } \\
\text { brick }\end{array}$ & 1530 & 0.7 & 2.182 & 3.009 & 3.009 \\
\hline Ceramic Tile & 2000 & 1 & 15.649 & 0.857 & 14.453 \\
\hline Stone tile & 2100 & 1.5 & 2.200 & 0.290 & 3.009 \\
\hline $\begin{array}{c}\text { Ceramic tile } \\
\text { of roof }\end{array}$ & 2000 & 1 & 4.590 & 0.406 & 2.456 \\
\hline $\begin{array}{c}\text { Concrete tile } \\
\text { of roof }\end{array}$ & 2380 & 1.65 & 2.659 & 0.270 & 4.104 \\
\hline $\begin{array}{c}\text { Fiber cement } \\
\text { of roof }\end{array}$ & 1800 & 0.5 & 11.543 & 1.392 & 20.368 \\
\hline
\end{tabular}

\section{INSULATION MATERIALS}

It is better to point out that, the impact of industrial products is far more than natural materials such as wood fiber, natural fiber or recycled materials such as cellulose fibers. As long as products like polyurethane with $\mathrm{CO} 2$ emissions produce equivalent $7 \mathrm{~kg}$ and much crude oil and gas for its production, natural insulations such as wool spread CO2 gas to a very small extent $(0.987 \mathrm{~kg})$. Another advantage of this product is the possibility of its recycling. Due to the high volume of using natural fibers, wool sheep industry is currently declining and due to its low supply in the market, in most cases, combined materials are used in the field (Zabalza et al, 2010). Cork can be a good choice in the field of insulation materials. This is due to the cheapness and availability of this product. And the other benefits of environmentally friendly product is the extraction of it from forests in the form of every 10 years, this could help the ecosystem. However, its primary energy production is relatively high, in addition, 50\% of energy from biomass sources is provided which reduces its use. Polyurethane sheets expanded and rigid polystyrene foams have the highest heating insulation. In contrast of these products, rock wool is placed that its required primary energy 4 times, the effect of its carbon 4.7 times and its moisture effect up to 8.4 times less than the above cases. However, rock wool requires relatively high consumption of coal to be combined well with basaltic rocks, and also needs to synthetic polymer resins to have a good quality. Despite all this, we need a general understanding of the design to through that, depending on the project and the costs and climate reach to a general consensus on the field of choosing materials and at the same time we can reduce the negative effects on nature.

Table 3: LCA findings from insulation materials

\begin{tabular}{|c|c|c|c|c|c}
\hline $\begin{array}{c}\text { Building } \\
\text { Products }\end{array}$ & $\begin{array}{c}\text { Density } \\
(\mathrm{kg} / \\
\mathrm{m} 3)\end{array}$ & $\begin{array}{c}\text { Thermal } \\
\text { conductivity } \\
(\mathrm{W} / \mathrm{mK})\end{array}$ & $\begin{array}{c}\text { Primary } \\
\text { required } \\
\text { energy }(\mathrm{MJ}- \\
\mathrm{Eq} / \mathrm{kg})\end{array}$ & $\begin{array}{c}\text { warming } \\
\text { potential of } \\
\text { earth } \\
(\mathrm{Kg} \mathrm{CO} 2-\mathrm{Eq} / \\
\mathrm{kg})\end{array}$ & $\begin{array}{c}\text { Amount of water } \\
\text { needed } \\
(\mathrm{L} / \mathrm{kg})\end{array}$ \\
\hline $\begin{array}{c}\text { EPS sheet } \\
\text { foam }\end{array}$ & 30 & 0.0375 & 105.486 & 7.336 & 192.729 \\
\hline Rock wool & 60 & 0.04 & 26.393 & 1.511 & 32.384 \\
\hline $\begin{array}{c}\text { polyurethane } \\
\text { rigid foams }\end{array}$ & 30 & 0.032 & 103.782 & 6.788 & 350.982 \\
\hline Cork & 150 & 0.049 & 51.517 & 0.807 & 30.337 \\
\hline $\begin{array}{c}\text { Cellulosic } \\
\text { fibers }\end{array}$ & 50 & 0.04 & 10.487 & 1.831 & 20.789 \\
\hline Wood wool & 180 & 0.07 & 30.267 & 0.124 & 2.767 \\
\hline \multicolumn{5}{c}{ (Zabalza et al, 2010) }
\end{tabular}

\section{CEMENT AND CONCRETE}

Normally 40 to $60 \%$ of the total weight of the building is formed of these products, which also have significant negative environmental effects. The environmental effect of reinforced concrete is much more that non-reinforced concrete, this is due to the use of ribbed bars that is sticking to concrete and 
causing building non-recyclable materials. As a result, its primary energy required is increased $700 \mathrm{Mj}-\mathrm{Eq} / \mathrm{t}(63 \%)$ and its $\mathrm{CO} 2$ emissions by as much as $42 \mathrm{~kg} / \mathrm{t} \mathrm{(31 \% )} \mathrm{will} \mathrm{increase.} \mathrm{Notably,} \mathrm{the}$ use of lime mortar is instead of cement mortar that in terms of handling and transport and $\mathrm{CO} 2$ emissions during construction can reduce carbon emissions to $62 \%$. It should be noted that the environmental impacts is due to manufacturing process of clinker brick significantly high. This effect can be reduced by production using ecological and recycled products significantly. Now in most European countries, these products as alternatives of non-renewable products are used and use them is only $35 \%$ (the figure is $80 \%$ in the Netherlands) and in Spain, the figure is less than $5 \%$. The use of alternative fuels in cement production process can reduce its environmental effects, so it can be changed waste products into recycled products using recycled materials in the process. Compare the actual amount of energy consumption in clinker furnaces that some is among $2900-3200 \mathrm{Mj} / \mathrm{t}$ and its supposed amount is equal to $1700-1800 \mathrm{Mj} / \mathrm{t}$, the figure is very high, by 2050 this rate should be (based on emissions protocol CO2) reduced by half (Habert et al, 2010). This figure can be reduced with technology of fuel sedimentary materials (use wastes left by the furnace slag and convert them into liquid and burn them again) reduced (Zabalza et al, 2010). Concrete is one of the materials that play an important role in the field of energy. Concrete is considered as one of the sources of CO2. To the extent, that this produces $70 \% \mathrm{CO} 2$ of the world (Calkins, 2009). For example, according to one study, about $99 \%$ of $\mathrm{CO} 2$ emissions in three bedrooms of a house in Scotland have been due to the use of concrete walls. Blengini states that recycled concrete can be included $19 \%$ of the total volume of concrete consumed (Blengini, 2009). In another study it was observed that extract of aggregates that is used for mixing in the concrete needs to $20 \mathrm{kj} / \mathrm{kg}$ oil and $9 \mathrm{kj} / \mathrm{kg}$ electricity, breaking and demolition of the concrete needs to $120 \mathrm{kj}$ oil and $50 \mathrm{kj}$ electricity. In another study found that only benefit of concrete when it is recycled, which can be used its pieces instead of combination aggregates (Dodoo et al, 2010).

Figure 5: The amount of $\mathrm{CO} 2$ emissions resulting from the processing and production of building materials in terms of 1 sq.m

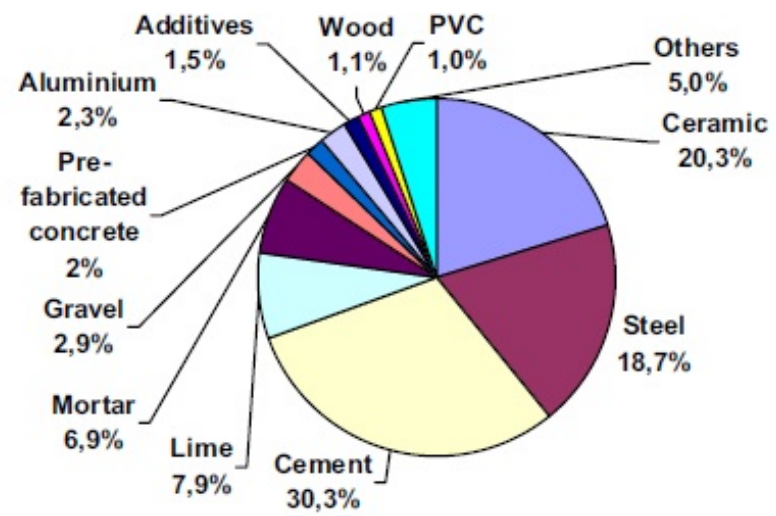

(Cuchí et al., 2007)

Another way to reduce the environmental effects of concrete is the use of it in the replacement of natural aggregate with recycled products such as sand, brick, crushed plastic, fiberglass wastes, wood chips, etc. (Joseph, 2010). However, the integration of products is not as well as industrial and chemical products of manufacturing. As a result some of the attachments of concrete mixture that are naturally prepared not operate as well as manufacturing and industrial products. Despite all these problems, recycled concrete can be used in different places, for example Redford airport in the United States to build used 6.5 million tons of recycled concrete. Frequency of use of concrete is due to increase of its physical power against building products, which increased the use of this product (Herbert and Rouse, 2000 :). Another type of concrete that with a high performance is produced in France is ductal concrete. The concrete compared to ordinary concrete has the $65 \%$ saving in the use 
of renewable materials, reducing $51 \%$ of primary energy and reducing $\mathrm{CO} 2$ emissions by as much as $47 \%$. Also its physical capacity is increased and its compressive strength is 6 to 8 times, bending strength to 10 times more and its durability is between 10-100 times better (Damtfot et al, 2008). Some researchers suggest alternative materials, for example Haberman and Pearl Mather concluded in a research on Negev desert houses that if, instead of reinforced concrete, we used the replacement materials such as foam concrete blocks, blocks of reinforced soil or sand, embodied energy is reduced by $20 \%$ (Huberman and Pearlmutter, 2008). In similar conditions, the use of refractory brick can be effective. The energy required for the production of refractory brick $(657.1 \mathrm{Mj} / \mathrm{t})$ than conventional brick $(4186.8 \mathrm{Mj} / \mathrm{t})$ is much less. The index shows a decline of about 6.4 times (Oti et al, 2009). This traditional building materials while are inexpensive have appropriate heating and acoustic properties. And at the end of their useful life can be used as leaven of other products or even return to nature. However, refractory brick loses its durability against water, water can deplete it, but the problem is also solved by covering this product. In some cases, the stone can also be a good alternative to concrete or ceramic. When the stone is available or could be extracted it in sufficient quantities, can reduce the environmental impact of the building to an acceptable level.

Looking at remained buildings from the 19th and early 20th century, researchers can understand their performance and durability by an accurate assessment (Calas et al, 2010; Mandell et al., 2010). Racks also can be an appropriate alternative for ceramic. Nikoltti and others in a study compared marble rock and ceramic as decking. They concluded that the environmental impacts of marble rock are less than 2.2 times ceramic (Nicoletti et al, 2002). Metals (steel, aluminum, copper, etc.) have much more embodied energy compared to concrete (aluminum $191 \mathrm{Mj} / \mathrm{g}$, steel $32 \mathrm{Mj} / \mathrm{kg}$, concrete $1.30 \mathrm{Mj}$ / $\mathrm{kg}$ ). As a result, if they even contain a small part of the overall volume of the building, the total amount of embodied energy will increase sharply. For example, Chen investigated a research on two high-rise residential buildings in Hong Kong. In these cases, steel and aluminum used in buildings included around $75 \%$ of the total embodied energy of building (Chen et al, 2001: ??). However, a relatively small amount of concrete was used in these two buildings; embodied energy of metal can be reduced substantially in the case of being recycled. They also pointed to the fact that the volume of energy for recycled steel is $10 \mathrm{Mj} / \mathrm{kg}$ as well as for recycling aluminum are $8 \mathrm{Mj} / \mathrm{kg}$ that the figure included $31 \%$ of energy consumption for production of pure steel and $4 \%$ of pure aluminum (Blengini, 2009). Gustavsson and Sathre, 2006 achieved similar results, although their numbers with the numbers obtained was slightly different. As a result, the use of recycled aluminum and steel has the ability to reduce energy embodied about $50 \%$. More benefits show themselves when building has reached to the end of its useful life and we want to recycle its materials. However, according to research that Dodu and others conducted, the reserves recycled of metals have increased and thereby useful return of energy recycled at the end of life of the building reduces (Dodu et al, 2010). Renewable energy potential of recycled metals has caused leading these materials, which can be used the recycled materials as a proper substitute for concrete in non-structural elements of the building. (Chen et al, 2001).

Table 4: The results of LCA from cement and concrete

\begin{tabular}{|c|c|c|c|c|c}
\hline $\begin{array}{c}\text { Building } \\
\text { Products }\end{array}$ & $\begin{array}{c}\text { Density } \\
\text { (kg/ } \\
\mathrm{m} 3)\end{array}$ & $\begin{array}{c}\text { Thermal } \\
\text { conductivity } \\
(\mathrm{W} / \mathrm{mK})\end{array}$ & $\begin{array}{c}\text { Primary } \\
\text { required } \\
\text { energy }(\mathrm{MJ}- \\
\mathrm{Eq} / \mathrm{kg})\end{array}$ & $\begin{array}{c}\text { warming } \\
\text { potential of } \\
\text { earth } \\
(\mathrm{Kg} \mathrm{CO}-\mathrm{Eq} / \\
\mathrm{kg})\end{array}$ & $\begin{array}{c}\text { Amount of water } \\
\text { needed } \\
(\mathrm{L} / \mathrm{kg})\end{array}$ \\
\hline $\begin{array}{c}\text { Cement } \\
\begin{array}{c}\text { Cement } \\
\text { mortar }\end{array}\end{array}$ & 3150 & 1.47 & 4.235 & 0.819 & 3.937 \\
\hline $\begin{array}{c}\text { Reinforced } \\
\text { concrete }\end{array}$ & 2546 & 0.7 & 2.171 & 0.241 & 3.329 \\
\hline Concrete & 2380 & 1.65 & 1802 & 0.179 & 2.768 \\
\hline \multicolumn{7}{c}{ (Zabalza et al, 2010) } \\
\hline
\end{tabular}




\section{WOODEN PRODUCTS}

When concrete was proposed as a cost to the environment, wood had a very good reputation. Articles generally agreed that wooden structures have low required energy and less $\mathrm{CO} 2$ emissions (Cole and Kernan, 1995; Borjesson and Gustavsson, 2000; Treloar, 2002; Petersen and Solberg, 2005). Wooden materials have a suitable performance as carbon storage over the life of the building and this is much more than trees that have not been cut yet (Borjesson and Gustavsson, 2000). In general, all woodbased materials have minimal impact on the environment, particularly those materials that do not require processing in industrial plants. Primary energy of all these products is supplied by biomass. The amount of $\mathrm{CO} 2$ gas emissions by this category of products is almost zero. It must be considered that per cubic meter of wooden laminate absorbs $582 \mathrm{~kg} \mathrm{CO} 2$ gas, while the concrete per cubic meters releases $458 \mathrm{~kg} \mathrm{CO} 2$ gas, it is in relation to the steel is equivalent to $12.087 \mathrm{~kg}$. The use of wood can reduce the running costs of the building and also reduce the environmental impacts and global warming (caused by greenhouse gas emissions).

Table 5: results of LCA from wood-based materials

\begin{tabular}{|c|c|c|c|c|c}
\hline $\begin{array}{c}\text { Building } \\
\text { Products }\end{array}$ & $\begin{array}{c}\text { Density } \\
(\mathrm{kg} / \\
\mathrm{m} 3)\end{array}$ & $\begin{array}{c}\text { Thermal } \\
\text { conductivity } \\
(\mathrm{W} / \mathrm{mK})\end{array}$ & $\begin{array}{c}\text { Primary } \\
\text { required } \\
\text { energy (MJ- } \\
\text { Eq / kg) }\end{array}$ & $\begin{array}{c}\text { warming } \\
\text { potential of } \\
\text { earth } \\
(\mathrm{Kg} \mathrm{CO}-\mathrm{Eq} / \\
\mathrm{kg})\end{array}$ & $\begin{array}{c}\text { Amount of water } \\
\text { needed } \\
(\mathrm{L} / \mathrm{kg})\end{array}$ \\
\hline $\begin{array}{c}\text { Logs, soft } \\
\text { wood, } \\
\text { smooth, dry } \\
\text { by kiln }\end{array}$ & 600 & 0.13 & 20.996 & 0.3 & 5.119 \\
\hline $\begin{array}{c}\text { Logs, soft } \\
\text { wood, } \\
\text { smooth, dry } \\
\text { by air }\end{array}$ & 600 & 0.13 & 18.359 & 0.267 & 4.195 \\
\hline $\begin{array}{c}\text { Wooden } \\
\text { laminated } \\
\text { used in } \\
\text { building }\end{array}$ & 600 & 0.13 & 27.309 & 0.541 & 8.366 \\
\hline $\begin{array}{c}\text { Chipboard } \\
\text { used inside } \\
\text { the building }\end{array}$ & 600 & 0.13 & 34.646 & 0.035 & 8.788 \\
\hline $\begin{array}{c}\text { wooden } \\
\text { board }\end{array}$ & 600 & 0.13 & 36.333 & 0.62 & 24.761 \\
\hline
\end{tabular}

(Zabalza et al, 2010)

\section{CONCLUSION}

In this paper, in response to the increasing difficulty of building wastes in the country, producing new materials from the point of view of new resources of products and methods for product recovery after consumption was suggested, to through pay attention to ecological trends in the construction and use, environmental load reduces in producer and consumer part. In this context, eco-friendly materials in residential complexes on Tehran in order to reduce energy consumption are as follows :

Taking advantage of ceramic products to $1.93 \mathrm{MJ} / \mathrm{Kg}(42 \%)$ on the floor as well as rocks can be a proper alternative to ceramic.

The use of refractory brick can also be effective. The energy required for the production of refractory brick $(657.1 \mathrm{Mj} / \mathrm{t})$ than conventional brick $(4186.8 \mathrm{Mj} / \mathrm{t})$ is much less as well as enjoying the right clay brick ( $85 \%$ clay soil and $15 \%$ straw) calcium silicate brick ( $9 \%$ limestone and $10 \%$ sand).

Use insulations that a higher percentage of recycled and waste materials are used in their manufacture and also for filling containers, bulk rock wool and cellulose should be used that have the percent of 
more recycled material than fiberglass. The use of lime mortar is instead of cement mortar that reduces handling and transportation as well as $\mathrm{CO} 2$ emissions. Instead of reinforced concrete, we should use replacement materials such as foam concrete blocks, blocks of reinforced soil or sand to work. Replacement of natural aggregate with recycled products such as sand, brick, crushed plastic, fiberglass wastes, wood chips, etc. is in order to reduce the environmental impacts of concrete . The use of recycled metals (aluminum and steel recycling) as a substitute for concrete in non-structural elements of construction should be introduced. The use of wood can reduce the running costs of the building and also reduce the environmental impacts and global warming (caused by greenhouse gas emissions).

\section{REFERENCES}

Ebrahimi, H. (2011), new energies in Iran, Resalat newspaper, No. 7489, Tehran.

Babaei Finni, Om Alsalameh - Farajzadeh, M. (2003), local indices of precipitation and its changes in Iran, the third regional conference and the first International Conference on Climate Change (university of Esfahan)

Bai, N. (2010), analysis and forecasting of climatic elements in Gorgan, Journal of geographic perspective of Zagros, Issue 4.

Parvardi Nejad, Samira. Zandie, M. (2010). Sustainable development and its implications in Iran's housing architecture, housing Magazine of rural environment, Tehran.

Pourdeihimi, Sh. (2011), climate language in sustainable environmental design, Shahid Beheshti University, Tehran, Iran.

Hatami Golzari, E. (2008), traditional architecture of Iran and sustainable development, infrastructure engineering magazine, Issue 6 , Tehran.

Khosravi, Mahmood - Javdani Khalife, Naser- Mohammadnia Gharaei, S. (2003), verify compliance of time series of Mashhad temperature with changes and fluctuations in global temperature, the third regional conference and the first International Conference on Climate Change (university of Esfahan). Sayadi, Seyed Ehsan- Madahi, Seyed Mehdi (2011), sustainable architecture, Lutz, Tehran.

Tahbaz, Mansureh- Jaliliyan, SH, (2011), Principles of architectural design in harmony with the climate in Iran, Shahid Beheshti University, Tehran .

National Building Regulations Section XIX (2002), savings in energy consumption, develop and promote National Building Regulations Office, Ministry of Housing and Urban Development, Tehran, Iran's development of publishing.

Mehdikar, Siamak (2011), sustainable architecture and its components, the Ministry of Education, Ghazvin.

Yousefi Najaf-Abadi, M. (2009), an introduction to the design of ecological, landscape and environment magazine, No. 59, Tehran

Adalberth K. (2001). Energy use in four multi family buildings. Int J Low Energy Sustainable Build.<http://bim.ce.kth.se/byte/leas.<

Ahmadi F. (2002). Sustainable architecture. Population quarterly.

Aivazian S. (1998). Use of traditional methods in energy saving. Fine Arts journal.

Anastaselos D, Giama E, Papadopoulos AM. (2009). An assessment tool for the energy, economic and environmental evaluation of thermal insulation solutions. Energy and Buildings;41(11).

Ardente F, Beccali M, Cellura M, Mistretta M. (2008). Building energy performance: a LCA case study of kenaf-fibres insulation board. Energy and Buildings; 40 .

Ardente F. (2005). Life cycle assessment of a solar thermal collector. Renew Energy; 30(7).

Arjen M, Mark Aj H, Lucas R. (2005). Human health damages due to indoor sources of organic compounds and radioactivity in life cycle impact assessment of dwellings. Int $\mathrm{J}$ Life Cycle Assess; $10(6 .($

Arena AP, Rosa C. (2003). Life cycle assessment of energy and environmental implications of the implementation of conservation technologies in school buildings in Mendoza - Argentina. Build Environ; 38.

Armaghan M., Gorji Y. (2008). Local values of Iranian architecture in relation with theapproach to sustainable architecture. Monthly housing, environment and village.

Asif M, Muneer T, Kelley R. (2007). Life cycle assessment: a case study of a dwelling home in Scotland. Building and Environment; 42(3). 
Askham NC. (2006). Excel for calculating EPD data for Concrete. In: SETAC Europe 13th LCA case study symposium proceedings with focus on the building and construction sector, Stuttgart, Germany. p. 142.

Aslani F., Aslani M. (2001). Study of designing methods for sustainable architecture in savingand optimizing the energy consumption in the building. First convention on the optimization of fuelconsumption. Tehran.

Azerbaijani M., Mofidi, M. (2001). Concept of sustainable architecture. presented in conference on optimizing of fuel consumption in the building.

Bisset R. (2007). Buildings can play a key role in combating climate change. UNEP news release . $>$ http://www.unep.org/Documents.Multilingual/Default.asp?DocumentID=502\&ArticleID=5545\&l=e $\mathrm{n}>$; [accessed 29.07.03].

Blengini GA. (2009). Life cycle of buildings, demolition and recycling potential: a case study in Turin, Italy. Building and Environment; 44.

Blengini, G.A.; Di Carlo, T. (2010). The changing role of life cycle phases, subsystems and materials in the LCA of low energy buildings. Energy Build; 42.

Borg M. (2001). Environmental assessment of materials, components and buildings. Building specific considerations, open loop recycling, variations in assessment results and the usage phase of buildings. $\mathrm{PhD}$ thesis; ISBN 91-7283-159-6.

Brundtlandreport.(1987).<http://www.are.admin.ch/themen/nachhaltig/00266/00540/00542/index.htm 1?lang=en $>$; [accessed 10.06.06].

Boustead, I. (1997). The Boustead Model 3 for Life Cycle Inventory Calculations.Boustead Consulting Ltd, UK.

Chavan A. (2005). Self-cleaning concrete to fight pollution. $<$ http://www.planetizen.com/node/16887>; [accessed 03.03.07].

Citherlet S, Di Guglielmo F, Gay JB. (2000). Window and advanced glazing systems life cycle assessment. Energy Build; 32(3).

34]Chen HY. Ganesan, S. Jia, BS. (2005). Environmental challenges of postreform housing development in Beijing. Habitat Int;29(3).

Cole RJ, Kernan PC. Life-cycle energy use in office buildings. Building and Environment 1996; 31(4).

Datschefski E. (2001). The Total Beauty of Sustainable Products.

Erlandsson M, Borg M. (2003). Generic LCA-methodology applicable forbuildings, constructions and operation services - today practice anddevelopment needs. Build Environ; 38(7).

Erlandsson M, Levin P. (2005). Environmental assessment of rebuilding and possible performance improvements effect on a national scale. Build Environ;40(11).

Edward B. (2010).guidelines towards sustainable architecture. Translator Iraj Shahrooz Tehrani.Tehran: Mehrazan publications.

Fava JA. (2006). Will the next 10 years be as productive in advancing lifecycle approaches as the last 15 years? Int J Life Cycle Assess; 11.

Fay R., Treloar G, Iyer-Raniga U. (2000). Life-cycle energy analysis of buildings: a case study. Build Res Inform;28(1).

Frischknecht R, Jungbluth N, Althaus HJ, Doka G, Dones R, Heck T, et al. (2005). The ecoinvent database: overview and methodological framework. International Journal of Life Cycle Assessment;10(1).

Forsberg A, von Malmborg F. (2004). Tools for environmental assessmentof the built environment. Build Environ;39.

Gregory AN., Yost P. (2002). A transparent, interactive software environment for communicating life cycle assessment results. J Indus Ecol;5(4).

Green Building Challenge (GBC). (2000). Stockholm: The Swedish Council for Building Research.

Gustavsson L, Joelsson A, Sathre R. (2010). Life cycle primary energy use and carbon emission of an eight-storey wood-framed apartment building. Energy and Buildings;42(2).

Hellweg S, Hofstetter TB, Hungerbuhler K. (2003). Discounting and theenvironment - should current impacts be weighted differently thanimpacts harming future generations? Int J Life Cycle Assess; $8(1)$. Hernandez, P.; Kenny, P. (2010). From net energy to zero energy buildings: Defining life cycle zero energy buildings (LC-ZEB). Energy Build. 42. 
Hertwich EG. (2005). Life cycle approaches to sustainable consumption: acritical review. Environ Sci Technol;39(13).

Houghton JT et al. (2001). Climate change 2001: the scientific basis. Contribution of working Group I to the third assessment report of the intergovernmental panel on climate change (IPCC). IPCC Cambridge University Press.

Huberman N, Pearlmutter D. (2008). A life-cycle energy analysis of building materials in the Negev desert. Energy and Buildings;40.

Huijbregts MAJ et al. (2003). Evaluating uncertainty in environmental lifecycleassessment. A case study comparing two isolation options for aDutch one-family dwelling. Environ Sci Technol;37(11).

HUT (1993) Target costs for facility managers. Report 119. Helsinki University of Technology, Faculty of Civil and Environmental Engineering, Construction Economics and Management. Espoo, Finland.

IEA, Hobday R. (2006). Energy related environmental impact of buildings,technical synthesis report annex 31:International energy agencybuildings and community systems. $<$ http://www.ecbcs.org/docs/annex_31_tsr_web.pdf $>$; [accessed 02.11.06].

International Standardization Organization (ISO). (2006). Environmentalmanagement - life cycle assessment - principles and framework; ISO 14040.

Izadi Yar A. (2011). The role of sustainable energy in architecture. Islamic Azad University, Tehran"scentral branch.

Janssen GMT, Hendriks ChF. (2002). Sustainable use of recycled materials in building construction. Advances in Building Technology.

Junnila S. (2006). Life cycle assessment of office buildings in Europe and the United States. J Infrastruct Syst;12.

Jian G, Jiang L, Kazuroni H. (2003). Life cycle assessment in the environmental impact evaluation of urban development - a case study of land readjustment project, Hyogo District, Japan. J Zhejiang Univ Sci;4(6).

Klopffer W. (2006). The role of SETAC in the development of LCA. Int JLife Cycle Assess; 11.

Kasmaei M. (1999). climate and architecture. Tehran, Iran. ISBN: 9645583470.

Kotaji S, Edwards S, Schuurmans A. (2003). Life cycle assessment in building and construction. A state-of-the-art report. Florida: SETAC press.

Kellenberger D, Althaus H- J. (2009). Relevance of simplifications in LCA of building components. Building and Environment;44.

Khasreen M, Banfill P, Menzies G. (2009).Life-cycle assessment and the environmental impact of buildings: a review. Sustainability;1(3).

Larsson N. (2006). Sustainable building information systems (SBIS). $<$ http://www.sbis.info/about.jsp>; [accessed 28.01.07].

Li ZG. (2006). A new life cycle impact assessment approach for buildings. Build Environ;41(10).

Lutzkendorf T., Lorenz DP. (2006). Using an integrated performance approach in building assessment tools. Build Res Inform;34(4).

Lindfors, L.-G., Christiansen, K., Hoffman, L., Virtanen, Y., Juntilla, V., Hanssen, O.- J., Rønning, A., Ekvall, T. and Finnveden, G. (1995).Nordic guidelines on life cycle assessment. Nord :20. Nordic Council of Ministers, Copenhagen, Denmark.

Nebel B, Zimmer B, Wegener G. (2006). Life cycle assessment of wood floorcoverings - a representative study for the German flooring industry.Int J Life Cycle Assess;11(3).

Nicoletti GM, Notarnicola B, Tassielli G. (2002).Comparative life cycleassessment of flooring materials: ceramic versus marble tiles. JCleaner Production;10(3).

Nyman M, Simonson CJ. (2005). Life cycle assessment of residential ventilation units in a cold climate. Build Environ;40(1).

Ortiz O., Castells F., Sonnemann G. (2007). Important issues in LCA and ecodesign within the building sector for developing countries. In: International conference on life cycle assessment CILCA-Sao Paulo, Brazil.

Parsi F. (2008). Climatic spaces in Iranian architecture. Architect journal.48.

Paulsen JH., Borg M. (2003). A building sector related procedure to assess the relevance of the usage phase. Int J Life Cycle Assess;8(3). 
Petersen AK, Solberg B. (2005). Environmental and economic impacts ofsubstitution between wood products and alternative materials: areview of micro-level analyses from Norway and Sweden. ForestPolicy Econom;7(3).

Peuportier BLP. (2001). Life cycle assessment applied to the comparative evaluation of single family houses in the French context. Energy Build;33(5).

Procter E, Gamble S. (2005). Life cycle impacts assessment (LCIA). Endpoints versus mid points. $<$ http://www.scienceinthebox.com/en_UK/sustainability/lcia_en.html>; [accessed on 05.04.06].

Prek M. (2004). Environmental impact and life cycle assessment of heating and air conditioning systems, a simplified case study. Energy Build;36(10).

Runming Y., Baizhan L., Koen S. (2005). Energy policy and standard for built environment in China. Renew Energy;30(13).

Sartori I, Hestnes AG. (2007). Energy use in the life-cycle of conventional and lowenergy buildings: a review article. Energy and Buildings; 39.

Schleisner L. (2000). Life cycle assessment of a wind farm and related externalities. Renew Energy;20(3).

Sun J, Han B, Ekwaro-Osire S, Zhang H. (2003). Design for environment: methodologies, tools and implementation. J Integrated Des Process Sci; 7(1).

Sustainable steel construction (2006). - building a better future. A sustainability strategy for the UK steel construction sector developed by the Steel Construction sector sustainability committee (SCSSC). $<$ http://scinews.steel-sci.org/articles/pdf/ASC.pdf>; [accessed 16.08.06].

Sonnemann G., de Leeuw B. (2006). Life cycle management in developing countries: state of the art and outlook. Int J Life Cycle Assess ; 11.

The building and construction sector: moving towards sustainability.Sustainable Building and Construction Forum. <http://www.unep.or.jp/ietc/sbc/index.asp > [accessed 15.09.06].

Taborianski VM, Prado RTA. (2004). Comparative evaluation of thecontribution of residential water heating systems to the variation ofgreenhouse gases stock in the atmosphere. Build Environ; 39(6).

Tattersall, C. (2007). LEEDing the way, Design Quarterly,Canada.

Tillman A-M. (2000). Signi2cance of decision-making for LCAmethodology. Environmental Impact Assessment Review; 20.

US Energy Information Administration Statistics.

$<$ http://www.architecture2030.org/building sector/index.html >; [accessed 25.02.07].

USGBC (United States Green Building Council). (2012) Pilot Credit 63: MR-While Building Life Cycle Assessment; USGBC: Washington, DC, USA.

Vázquez M. (2001). Building and Impact on the environment: the case of the earth and other materials; 52 (471).

Warburg N et al.(2005). Environmental indicators for ICT products - apractical approach based on four steps. The International Society ofEcological Economics.

Wren \& Bell. (2001). Sustainable construction. $<$ http://www.sustainableconstruction.co.uk/sustainability.htm>; [accessed 25.06. 06].

Weidema BP. (1998). New developments in the methodology for life-cycleassessment, handout. Third International Conference on Ecobalance,Tsukuba.

Zabalza I., Aranda A., Scarpellini S. (2009). Life cycle assessment in buildings: State-ofthe-art and simplified LCA methodology as a complement for building certification.Building and Environment; 44.

www.suna.org.ir (Renewable Energy Organization of Iran, Sana

www.ipdc.ir Iran Power Development

$\mathrm{http}: / /$ www.sustainableabc.com/sustaindev.html

http://arch.hku.hk/research/BEER/sustain.htm\#1.1

http://www.earthpledge.org

http://www.um.ac.ir/ 